Alina Rynio*

Lublin

\title{
Charyzmat pedagogiczny ks. Luigiego Giussaniego
}

„Ja jestem zerem, Bóg jest wszystkim”.

\section{Wprowadzenie}

Z listu Jana Pawła II na pogrzeb ks. prałata Luigiego Giussaniego opublikowanego pod datą 22.02.2005 roku dowiadujemy się, iż papież z głebokim wzruszeniem przyjął wiadomość o jego śmierci. Znając go osobiście, podziwiał jego gorącą wiarę proponującą „towarzystwo" Chrystusa bardzo wielu młodym, którzy dzisiaj jako dorośli uznają go za swego duchowego „ojca” (p. 3). W tym niezwykle ciepłym i przyjacielskim liście Ojciec Święty zauważa, iż synteza życia i apostolatu „tego żarliwego mediolańskiego księdza” zawarta była w dwóch słowach: „Chrystus i Kościół”. Papież, doceniając w osobie Giussaniego „obrońcę ludzkiego rozumu" (p.4) i jego bezgraniczne oddanie się formacji młodzieży szkolnej, (p.3) zauważa, iż był on „dogłębnym znawcą literatury, muzyki i przekonanym promotorem sztuki jako drogi, która prowadzi do Tajemnicy" (p.4).

Niewątpliwie zmarły ks. Luigi Giussani należy do tych postaci XX w., które potrafiły zaświadczyć, że wychowanie człowieka rozumnie wierzącego i jego pełny rozwój to najważniejsze zadania i najlepsza inwestycja na przyszłość. Wyrażając potrzebę zaistnienia szczegółowych tematycznych monografii związanych z życiem i dziełem ks. L. Giussaniego w niniejszym szkicu, niejako na gorąco, spróbuję zarysować próbę odpowiedzi na kilka z wielu pytań związanych z jego charyzmatyczną posługą wychowawczą. Uwzględniając aspekt pedagogiczny, zwrócę uwagę na jego sposób rozumienia pedagogiki i wychowania i przywołam kilka faktów potwierdzających jego wyjątkowość jako człowieka, wychowawcy i uczonego.

* Dr hab. Alina Rynio, prof. KUL, kierownik Katedry Pedagogiki Chrześcijańskiej w Instytucie Pedagogiki Katolickiego Uniwersytetu Lubelskiego Jana Pawła II. 


\section{Istota pedagogiki i wychowania}

W ciagu swego 82-letniego życia, wychowując do wiary w Boga tysiące ludzi na całym świecie, mówił o pedagogice jako o ,sztuce uczenia rzeczy trudnych ludzi jeszcze niedojrzałych”. Wychowanie zaś rozumiał jako „odpowiednie komunikowanie przeszłości, przeżywanej w teraźniejszości i poddawanej pewnej krytyce”. Rozumiejąc wychowanie jako wprowadzanie w całość rzeczywistości, rację istnienia osoby upatrywał w jej sercu, w które natura wyposaża każde ludzkie dziecko.

Tak rozumiane wychowanie zaczyna się od ,ja” istniejącego w określonym miejscu i czasie. Jego bazą wyjściową jest to, kim jest człowiek i jakie są jego predyspozycje i przypadłości. Do istoty tak rozumianego wychowania należy otwartość na rzeczywistość, czyli to, co realnie istniejące, piękne, dobre i prawdziwe. Dla Giussaniego nie było najistotniejsze to, czego młodzi potrafią dokonać, ale to, kim są, jakie są ich predyspozycje i kim potrafią być. Swą bezkompromisową postawą życia i nauczaniem uformował tysiące młodych i dorosłych na całym świecie. Niewątpliwą pomocą w tym ,uczeniu rzeczy trudnych ludzi jeszcze niedojrzałych" jest założony przez niego w roku 1954 ruch kościelny Comunione e Liberazione i niezliczone wprost dzieła, które $\mathrm{z}$ tego charyzmatu się zrodzily. Wystarczy wspomnieć o międzynarodowym miesięczniku Tracce (Ślady) mającym kilka edycji językowych, w tym także polską, czy zrzeszającej ponad 6 tys. dzieł Compagnia delle opere.

\section{Krótki rys bigraficzny}

Mając na uwadze wyjątkowość posługi ks. Giussaniego, spróbuję zatrzymać się nad kilkoma faktami z jego życia i działalności. Bez wątpienia ten uważny i odważny teolog urodzony w Dezio dnia 15.10.1922 roku był postacią znaną i ceniona, nie tylko w życiu kościelnym, ale także kulturalnym i politycznym. 15.10.2002 r. na swoje osiemdziesięciolecie otrzymał ponad dwa tysiące życzeń, w tym specjalny list wyrażający uznanie dla jego dokonań i świadectwa życia od Ojca Świętego. W przededniu swoich osiemdziesiątych urodzin - w wywiadzie przeprowadzonym przez Dino Boffo - powiedział o sobie :,Ja jestem zerem, Bóg jest wszystkim". Jednym z wielu jego dokonań jest powołanie do istnienia - o czym już była mowa wcześniej - ruchu Comunione e Liberazione. Ruch ten istnieje dziś na wszystkich kontynentach w ponad siedemdziesięciu krajach, nie wyłączając Polski, gdzie znany jest pod nazwą Komunia i Wyzwolenie.

Niewątpliwie w osobie ks. L. Giussaniego, który wzorem św. Pawła wszystko kazał „badać a zachowywać jedynie to, co szlachetne”, mieliśmy do czynienia z kimś, kto bez wątpienia wszedł do historii Kościoła i religii jako świadek. Była to postać charyzmatyczna i wyjątkowa, co przyznają i szanują nawet ci, którzy nie uznawali i nie uznaja jego przesłania. 
Interesująca jest historia jego życia. Kiedy próbuje się ją śledzić, okazuje się, że ojciec był anarchizującym socjalista, a matka - jak sam wyznaje - „kobietą wyjątkowo piękną o wielkiej i prostej wierze". Jego dom rodzinny odznaczał się klimatem ogromnego szacunku wobec osoby oraz czynnym wychowaniem do ciagłego ożywiania prawdziwych wymiarów serca i rozumu. To dzięki rodzicom Giussani uczył się postrzegać rzeczywistość jako miejsce odsłaniania się człowiekowi tajemnicy Boga. W tym procesie odkrywania Boga jako zasady jednoczącej i wyjaśniającej całą rzeczywistość („Bóg wszystko we wszystkim i wszystkim we wszystkich") niebagatelne miejsce przypada Seminarium Duchownemu w Venegono, do którego Giussani wstąpił bardzo wcześnie, bo w wieku 10 lat. Jak sam po latach wyznaje, spotkał tu wybitnych profesorów takich jak: Gaetano Corti, Giovanni Colombo, Carlo Colombo, Carlo Figini. Ci profesorowie i autorzy przez nich polecani jak: Newman, Rosmini, Stoppiani, Manzoni uczyli i rozwijali jego inteligencję, wolność i wierność Kościołowi. Po święceniach kapłańskich w 1945 roku Giussani podejmuje wykłady w Seminarium Duchownym na Wydziale Teologicznym Archidiecezji Mediolańskiej, specjalizując się - co wówczas było rzadkością - w teologii wschodniej i protestanckiej. Interesuje go też rozumny charakter aktu wiary i motywacja przynależności do Kościoła. W roku 1954 na własne życzenie pozostawia pracę wykładowcy i własną karierę na rzecz obecności wśród młodzieży. $Z$ własnego wyboru zostaje nauczycielem religii $\mathrm{w}$ Liceum Klasycznym im. Berchet w Mediolanie. Z pracy tej jeszcze w latach pięćdziesiątych rodzi się organizacja o nazwie Gioventu studentesca (Młodzież uczniowska), która potem w latach 70-tych przerodzi się w ruch kościelny o nazwie Comunione e Liberazione (Komunia i Wyzwolenie).

\section{Ksiądz Giussanii jako wyjątkowy uczony i wychowawca}

Jego wyjątkowość manifestowała się poprzez to, kim był oraz sposób, w jaki wykładał, pisał, nauczał i działał. Będąc człowiekiem prawdziwie pokornym i nie pozwalając nazywać się mistrzem, kształcił mistrzów i był wszystkim dla wszystkich, aby ocalić przynajmniej niektórych. Kochał Pana Boga, człowieka i Kościół. Aktualnie do ruchu Komunia i Wyzwolenie przynależą dziesiątki tysięcy ludzi na całym świecie. Ks. Giussani był katechetą przez 10 lat, a duszpasterzem, myślicielem i niekwestionowanym autorytetem $\mathrm{w}$ sprawach wiary, moralności i wychowania - przez całe życie. Od roku 1964 pełnił funkcję profesora Uniwersytetu Katolickiego w Mediolanie. Przez wiele lat prowadził ogólnouniwersyteckie wykłady, które publikowano w formie książek wydawanych w tysięcznych nakładach. Problematyka w nich zawarta poświęcona jest między innymi teologii fundamentalnej, ontologii, podstawom antropologicznym, wychowaniu, moralności, znaczeniu literatury i muzyki w życiu religijnym. Niektóre z jego książek zostały przełożone na wiele języków, w tym także na język polski. Jedna z jego pozycji zatytułowana Zmyst religijny była przedmiotem międzynarodowej sesji 
w KUL zorganizowanej przez Instytut Pedagogiki. Materiały z tej sesji zostały opublikowane przez „Jedność” i noszą tytuł Wychowanie człowieka otwartego. Rola zmystu religijnego ks. Luigiego Giussaniego w kształtowaniu osoby. W 2002 roku w wydawnictwie tym ukazała się też bardzo ważna, szczególnie dla pedagogów, katechetów i rodziców, książka tego księdza pt. Ryzyko wychowawcze jako tworzenie osobowości i historii. Z licznych publikacji ks. Giussaniego w języku polskim dostępne są jeszcze: Śladami chrześcijańskiego doświadczenia, Doświadczenie jest droga do prawdy, Cała ziemia pragnie Twojego oblicza, Chrześcijaństwo jako wezwanie, Dlaczego Kościót? i inne.

Ksiądz L. Giussani był i pozostanie dla wielu postacią charyzmatyczna, to znaczy kimś, kto z łatwością rozpoznawał Boga żywego i obecnego i uczył świadomego przeżywania chrześcijaństwa w wymiarze misyjnym, także w życiu kulturalnym i społeczno-politycznym. Dla Giussaniego najważniejszy był Chrystus i to, co od Niego pochodzi. Dlatego też mógł on powiedzieć o swoim życiu, „iż ma nadzieję, że toczy się ono zgodnie z tym, czego Bóg od niego oczekiwał, a każda chwila jego życia była poszukiwaniem chwały Chrystusa i pokazywaniem Jego osoby”. Owo „pokazywanie” polegało na uobecnianiu tego, co Bóg już uczynił.

Ks. Giussani dał się poznać nie tylko jako nauczyciel religii czy profesor uniwersytecki, ale również jako założyciel i przewodniczący wyrosłych z ruchu stowarzyszeń kościelnych: Bractwa Comunione e Liberazione zrzeszającego blisko 40 tys. osób oraz rosnącego w liczbę, żyjącego dziewictwem i nieustanną pamięcią Pana Memores Domini i Bractwa św. Józefa uznanych przez Papieską Radę ds. Świeckich. Z czego rodziło się tak wielkie bogactwo osoby księdza Giussaniego i jego wychowawcza płodność? Dla tych, którzy go znali na co dzień odpowiedź jest prosta: ze sposobu przeżywania spotkania ze Słowem, „które ciałem się stało i zamieszkało między nami”. Szczegółowo o swoim spotkaniu z Chrystusem i wyrosłym z niego dziełem, jakim jest ruch Comunione e Liberazione, ks. Giussani zaświadczył na placu św. Piotra w Rzymie w dniu 30 maja 1998 r. Mówił wówczas: „to dzięki prostocie serca doświadczyłem i uznałem wyjątkowość Chrystusa z tą natychmiastową pewnością, jaka zdarza się w obliczu niekwestionowanej i niezniszczalnej oczywistości czynników i momentów rzeczywistości, które - $\mathrm{z}$ chwilą wejścia $\mathrm{w}$ przestrzeń osoby dotykają samej głębi serca. [...] Człowiek nie osiagga wielkości dzięki swoim zabiegom; wielkość przychodzi z łaski Boga jak piękny dzień (Camus, Zeszyty). Dla mnie wszystko wydarzyło się jak zaskoczenie pięknego dnia, kiedy nauczyciel w pierwszej klasie licealnej - miałem wtedy 15 lat - przeczytał i wyjaśnił pierwszą stronicę Ewangelii św. Jana. Wówczas czytano ją obowiązkowo pod koniec każdej Mszy Świętej; słyszałem ją więc wcześniej tysiące razy. Ale nadszedł piękny dzień: wszystko jest łaską. [...] Po czterdziestu latach, czytając ten fragment, zdołałem uchwycić, co się wydarzyło, kiedy ów nauczyciel wyjaśniał pierwszą stronicę Ewangelii św. Jana: „Słowo Boga, to, w czym wszystko ma istnienie, stało się ciałem - mówił - dlatego piękno stało się ciałem, dobro stało się ciałem, sprawiedliwość stała się ciałem, miłość, życie, prawda stały 
się ciałem: byt nie przebywa w platońskim «hiperuranium», [chodzi o świat ponad niebem, gdzie przebywają idee] byt staje się ciałem, jest jednym z nas. [...] Słowo stało się ciałem". Byt (piękno, prawda) nie tylko nie pogardził ciałem, by przyoblec w nie Swą doskonałość i podjąć troski człowieczego życia, ale więcej - przyszedł umrzeć za człowieka: „Przyszedł do swoich, a swoi go nie przyjęli”, zapukał do swojego domu, a nie poznano go. I to wszystko. Bo tym było odtąd ogarnięte moje życie: jako pamięć uparcie drążąca moje myśli i jako bodziec do przewartościowania banalnej codzienności. Chwila nie była już dla mnie czymś banalnym. Wszystko, co było - a więc wszystko, co było piękne, prawdziwe, pociaggające, nawet potencjalnie tylko - znajdowało swoją rację istnienia w tym orędziu, w pewności obecności i nadziei, która mobilizuje i pozwala objąć każdą rzecz".

Chcąc opisać ten niczym niepowstrzymany impet, jaki zagościł w sercu Giussaniego od momentu rozpoznania Chrystusa jako prawdy wszystkiego, należy użyć pojęcia pragnienie. Jest ono udziałem każdego prawdziwego misjonarza a wyraża się w tym, żeby wszyscy poznali to, co on poznał i żeby dla wszystkich „mógł wzejść ów piękny dzien'”. Jako drogę prowadzącą do poznania Chrystusa i przeżycia spotkania z Nim ks. Giussani proponował doświadczenie jedności. Manifestuje się ono w znaku zgody, przyjaźni i wspólnoty tych, którzy idą za Chrystusem i tym, co od Niego pochodzi. Uczył, iż „kiedy to uznajemy, wtedy jedność ta zaczyna pulsować i nasze życie staje się bardziej ludzkie. Wspólnota, rozszerzana bez granic, stanowi tajemnicę tej tożsamości, dzięki której i w której mogę powiedzieć Chrystusowi z drżeniem, lękiem i miłością: Ty!’”

Nic zatem dziwnego, że „wspólnota, towarzystwo, gdzie wydarza się spotkanie z Chrystusem, jest miejscem przynależności naszego ja, miejscem, od którego uczy się ono ostatecznego sposobu odbierania i rozumienia rzeczy, ich intelektualnego przyswajania i osądzania, planowania, projektowania, decydowania, robienia. Nasze ja przynależy do tego ciała, którym jest nasze towarzystwo i z niego czerpie kryterium w mierzeniu się ze wszystkim. Dlatego nasz punkt widzenia nie chodzi swoimi drogami, lecz zobowiązuje się do porównania i w porównaniu okazuje posłuszeństwo wspólnocie, towarzystwu".

Całą, przebogatą działalność wychowawczą ks. Giussaniego dobrze opisują jego własne słowa: „Jedyną racją, dla której zrobiliśmy to, co zrobiliśmy (i będziemy to robić, dopóki Bóg nam pozwoli), jedyną racją dla naszych zabiegów jest to, żeby Go poznali, żeby ludzie poznali Chrystusa. Bóg stał się człowiekiem, przyszedł do swoich: to, że swoi go nie znają, jest najcięższym grzechem, jest zdecydowanie największą niesprawiedliwością".

\section{Preferowane sposoby wychowania}

Rozumiejąc wychowanie jako wprowadzanie w to, co prawdziwe zawsze i wszędzie, i mając na uwadze choćby tylko treści zawarte w jego publikacjach 
takich, jak: wspomniane Ryzyko wychowawcze czy Zmyst religijny, należy stwierdzić, iż mamy tu do czynienia $\mathrm{z}$ wychowywaniem potwierdzającym to, co jest, co istnieje realnie. Giussani uczy, iż żyjący realnie człowiek wie, ,że najpierw go nie było, a teraz jest”. Zdaje też sobie sprawę, że „nie czyni się sam” i że niemal we wszystkim „zależy od kogoś innego”. Ma świadomość, że „może być albo mało znaczącym punkcikiem niesionym przez nurt historii, nieuchronnie pozostającym na łasce władzy, albo będąc relacją z owym tajemniczym X, niekończącym się horyzontem każdej myśli i każdego działania, jest tym, kim być powinien, a jego działanie można nazwać ludzkim, tzn. wolnym”. Owo tajemnicze X jest nośnikiem, wyjaśniającym rzeczywistość i odpowiedzią na ludzką potrzebę bycia prawdziwym, wolnym i szczęśliwym na zawsze. Tym X jest Słowo, które stało się człowiekiem i zamieszkało między nami - to Jezus Chrystus. Prawdziwy Bóg i prawdziwy człowiek, narodzony w czasie, z Maryi Dziewicy. Objawiając imię Boga i będąc ideałem i wzorem dla każdej ludzkiej egzystencji, niesie On wyzwolenie od niewoli grzechu, samotności i zagubienia. Będąc Prawdą, Drogą i Życiem wszystkiemu przywraca znaczenie, a dla wychowania staje się ,ideałem bez końca". Jego imieniem jest miłość i miłosierdzie. Pozostawanie w Nim czyni byt ludzki nowym stworzeniem. Daje mu nowy sposób patrzenia, myślenia, afektywności i działania. Ten nowy sposób bycia wyraża się w sprawiedliwości, która jest miłością, we właściwych relacjach międzyludzkich, w pojmowaniu wolności, przyjaźni czy pracy. Wyraża się w umiejętności osądu i życiu zgodnym z Bożym zamysłem. Naśladujący Jezusa z czasem zaczyna rozumieć, że każda praca wyraża się w świadomej relacji do siebie, do swojej duszy i swojego ciała, do ojca, matki, dziecka, pola, zakładu pracy, domu, i że nie ma żadnej rzeczy, żadnej relacji, która nie byłaby pracą. Tak rozumiana praca, podobnie jak wychowanie, otwarte Objawienie rodzi się z przyjaźni z Bogiem i rozwija się jako umiłowanie i pasja, towarzysząca wchodzącemu w relacje z jakąkolwiek rzeczą.

Giussani, charakteryzując wychowanie jako czynność otwartą na hipotezę Objawienia, wychodzi z założenia, iż kierujący się poczuciem realizmu i rozumnością człowiek, jest zdolny do osądu i przyjmowania postawy krytycznej. Zdolność ta wyraża się $w$ dążeniu do bycia realistą i traktowania świata jako miejsca objawiania się Tego, który go stworzył. Ks. Giussani, ucząc realistycznego patrzenia na własną osobę w działaniu, wyraża przekonanie, iż „racją bycia osoby jest dążenie do prawdy, sprawiedliwości, wolności i szczęścia bez końca”. Sądzi on, iż człowiek swą pewność moralną czerpie z poznania prawdy o sobie i otaczającym go świecie. Przyjmując zaś, że wiara jest darem, troszczył się o jej dojrzałość, wyrażającą się w tym, że „Chrystus przenika wszystkie rzeczy i jest obecny w historii poprzez osobowość ochrzczonego i komunię z braćmi”.

Bóg był dla niego rzeczywistością, którą można było spotkać. Uczył, że Obecność ta winna stawać się dla człowieka „hipotezą pracy”, bez której nie jest on w stanie zrozumieć siebie, drugiego i otaczającego świata. Samą wiarę definiował jako „coś, co rodzi się z zapatrzenia”, coś, co jest „wędrówką spojrzenia” i staje się adekwatną odpowiedzią na ostateczny sens egzystencji. Według niego, 
tak formowany człowiek nie tylko jest zdolny do krytyki i osądu, ale pokonuje pozorną dychotomię pomiędzy wiarą a rozumem, życiem i działaniem. Człowiek wychowywany przez Giussaniego do wiary wie, że nie jest miarą rzeczywistości, a kryteria osądu, jakie odkrywa w swoim sercu, są mu dane przez kogoś innego. Jest wychowywany do bycia uważnym, odważnym i zdolnym do podjęcia „ryzyka wolności, która otwiera go na oścież jak okno, na każdy aspekt rzeczywistości, także ten nieznany i tajemniczy". Wie też, że dla prawdziwego i pełnego rozwoju potrzebuje autorytetu, kogoś kto uosabia ową hipotezę wyjaśniającą rzeczywistość i żyje doświadczeniem wiary i miłości. Według włoskiego myśliciela w wychowaniu ważna jest też świadomość praw i powinności, rozwijanie zmysłu krytycznego, kategorii problemu i poczucia przynależności, nie wyłączając miłości do prawdy, gotowości do przemiany, ofiary i wyrzeczenia, akceptowania drugiego w jego odmienności, świadomości misji, odpowiedzialności, współdzielenia potrzeb czy konieczności pracy ascetycznej.

\section{Zdarzenia wychowujące}

Dla włoskiego myśliciela było oczywiste, że celem jego życia jest Chrystus, obecny we wspólnocie wierzących, ,znany i rozpoznawany jako Pan czasu i historii”, który poprzez wcielenie stał się towarzyszem jego ludzkiej drogi. Nic zatem dziwnego, iż formowany przez niego podmiot, świadom chrztu i bierzmowania, czuje się powołany do odczytania na nowo i zgodnie z Tradycją całego chrześcijańskiego doświadczenia. Kościół traktuje on jako miejsce zbawienia pochodzącego od Chrystusa. Równocześnie ks. Giussani uczył, że człowiek ochrzczony, dzieląc się doświadczeniem wiary, ma budować wspólnotę chrześcijańską tam, gdzie jest. Uczył też, iż życie ludzkie jest tkanką niezliczonej liczby zdarzeń i spotkań, poprzez które człowiek może być wychowywany. Wymaga to jednak od niego wielkiej pokory. Takim zdarzeniem wychowującym może być odkrycie sposobu wyrażania potrzeby poznawczej rozumu, doznanie estetyczne, przeżycie przyjaźni, piękna, miłości, zetknięcie się z dobrem, bądź jego świadczenie, urodzenie dziecka, własne lub cudze nieszczęście, czy też śmierć kogoś bliskiego. Zdarzeniem takim jest też odpowiednie komunikowanie przeszłości w teraźniejszości i zetknięcie się z autorytetem. Ten ostatni, podobnie jak Tradycja ujmowana krytycznie, jest ważny, ponieważ ,natura ustanowiła go jako normę każdego prawidłowego rozwoju". Stąd w wychowaniu rozumianym przez Giussaniego jako „odpowiednie komunikowanie przeszłości przeżywanej w teraźniejszości i poddawanej pewnej krytyce", istnieje potrzeba posiadania mistrza i nauczyciela, który wprowadza w to, co prawdziwe zawsze, wszędzie i dla każdego. Potrzeba kogoś, kto cieszyłby się autorytetem i pomógł odczytać kryteria osądu i rozwinać tak bardzo potrzebny ludziom młodym zmysł krytyczny. Potrzeba kogoś, kto pomógłby dzieciom i młodzieży zrozumieć samych siebie. Według Giussaniego, potrzeba nauczycieli, którzy nie tylko nauczają, ale też wychowują 
w duchu praw i powinności, którymi żyją sami. Potrzeba tych, którzy wychowują w duchu troski o godność i dobro każdego człowieka i ukazują godziwe warunki życia i pracy. Przywrócenie wychowawczej obecności w procesie wychowania jest koniecznością, ponieważ ważnym kryterium ludzkiego rozwoju jest to, że osoba uczy się jedynie wtedy, gdy ,idzie za”. Kiedy jest dzieckiem, czyni to niejako instynktownie; gdy staje się bardziej dojrzała, angażuje w to wolę, inteligencję i afektywność. Osoba uczy się, gdy czuje, że jest szanowana dla wartości, jaką w sobie nosi, gdy pozwala się jej być twórczą, samodzielną i swobodną.

\section{Elementy konstytuujące osobowość wychowującego i wychowywanego}

Giussani, wychodząc z założenia, iż wychowanie odpowiadające na potrzebę posiadania hipotezy objaśniającej rzeczywistość jest komunikowaniem siebie samego, zwraca uwagę na istotne elementy konstytuujące osobowość wychowującego i wychowywanego. Nie sposób omówić je wyczerpująco. Zatrzymam się więc na kilku wybranych: miłość do prawdy; doświadczenie żywej wiary, w tym wiary w istnienie dobra trudno osiagalnego (nadzieja); potrzeba przynależności; troska o dobro własne i innych; przeżycie wolnego wyboru; odpowiedzialność za to, do czego wzywa rzeczywistość; współdzielenie potrzeb z innymi na zasadzie międzyludzkiej solidarności; potrzeba posiadania własnej tożsamości i wrośnięcia w tradycję; dowartościowanie tego, co „tu i teraz”; otwartość na przyszłość; konieczność pracy nad sobą; uczenie się postawy bycia korygowanym i korygowania innych, wreszcie potrzeba przebaczania i akceptowania drugiego w jego inności.

Zauważmy, iż nie są to kwestie, od których możemy abstrahować, podejmując zaszczytną, choć trudną sztukę wychowania człowieka. Niewątpliwie przyjęcie Chrystusa i tego, co od Niego pochodzi, czyni proces wychowania łatwiejszym i skuteczniejszym, gdyż daje stabilny fundament i wskazuje na adekwatną metodę wychowania. Natomiast pamięć o Chrystusie, na którą ks. Giussani zwracał szczególną uwagę, pozwala dowartościować wszystko, co się wydarza w życiu $\mathrm{i}$ historii $\mathrm{i}$ jest potwierdzeniem tego bogactwa, jakie wypływa $\mathrm{z}$ doświadczenia chrześcijańskiego. Pamięć ta wzmacniana poprzez modlitwę i udział w liturgii rodzi jedność osoby, świadomość powołania i jedność chrześcijan, która uobecnia się i wyraża we wspólnotowości i jedności z prawowitym autorytetem kościelnym, nie mówiąc o dojrzałych osobowościach gotowych miłować nawet nieprzyjaciół. Według Giussaniego, pójście z Kościołem drogą wiary w Boga, który jest „wszystkim we wszystkim”, i Chrystusa, który jest „wszystkim we wszystkich", pozwala człowiekowi być tym, kim być powinien. Chroni go od nihilizmu, bezsensu, bylejakości, lęku, wyobcowania, anarchii, sceptycyzmu, beznadziei, egoizmu i nieodpowiedzialności. 


\section{Związek wychowania z wolnością, sumieniem i tradycją}

Na koniec tego wstępnego, jak mniemam, szkicu pozostaje mi jeszcze odpowiedzieć na pytanie, jaki jest stosunek tak rozumianego wychowania do wolności, sumienia i tradycji? Z analiz już poczynionych wynika, iż proponowane przez ks. Giussaniego wychowanie, uwzględniając potrzebę integralnego i harmonijnego rozwoju osoby, dowartościowuje rozum widziany w kategorii możliwości. Dowartościowuje też umiejętność czytania sensu znaczeń wewnątrz rzeczywistości, ale nie pomija wolności, prawego sumienia, uwagi, komunijnego charakteru realizowania się Bożego planu, ryzyka, potrzeby wychowania uczuć czy odpowiedzialności za to, do czego w danym momencie wzywa rzeczywistość. Mamy tu do czynienia z wychowaniem wrośniętym w tradycję i odzyskiwanie tego, co odziedziczyło się po przodkach przy równoczesnym dowartościowywaniu teraźniejszości i otwarciu na przyszłość. Takie wychowanie jest potwierdzaniem tego, co jest, co jest realne jak $2+2=4$. Ono ma swój ideał, który istnieje w czasie i jest ideałem bez końca, a mimo to da się uchwycić. Tym ideałem jest Bóg, który stał się człowiekiem. Fakt ten historycznie był i dalej jest powodem zgorszenia dla wielu podzielających mentalność kulturową naszej cywilizacji. Według Giussaniego, nierozpoznawanie tego ideału czyni nas kłamcami i sprawia, że zamiast prawdy widzimy kłamstwo i wedle niego żyjemy. Natomiast posiadanie ideału, jakim jest Chrystus, każe pracować nad myśleniem i samoświadomością, nad umysłem i sercem i każe podjąć ascezę, która jest tylko pozornym pójściem przeciw sobie.

Za niezwykle cenne w przywołanej tu zaledwie w zarysie wizji wychowawczej należy uznać nie tylko jej biblijne podstawy, ale również jej klasyczno-filozoficzne tło refleksji i możliwość praktycznego wykorzystania. O wychowaniu tym, podobnie jak o wezwaniu chrześcijańskim, można powiedzieć, iż jest jasną inicjatywą wobec każdego. Jest proste i zasadnicze. Zakłada spotkanie, dialog, rozumność, wolność, działanie, konkretność, integralność, kulturę, miłość, współdziałanie, osobiste zaangażowanie, funkcjonalność i autorytet. W osobie księdza Giussaniego kontemplującego dziś tak bardzo mu drogą Obecność Jezusa Chrystusa, którą uczył nas poznawać i miłować, rozpoznać możemy kochającego nas ojca jak nigdy przedtem.

\section{Pedagogical Charisma of Father Luigi Giussani (Summary)}

In this paper academic, pedagogical and social life of an Italian priest, thinker and a scholar, famous for his numerous achievements prof. Luigi Giussani is depicted.

Undoubtedly, his assets: attentiveness, discernment and courage made him a wellknown and respected person in academic, ecclesiastical, cultural and political life. 
The author of the paper, considering a pedagogical aspect, shows Giussani as an exceptional scholar and educator. His way of understandin of pedagogy and upbringing as well as selected achievements are presented. As an educator, Giussani was characterized by a realistic approach to a man and his upbringing. He emphasized the fact, that a man is a sensible and free being. Giussani dedicated himself both to God and a man.

A short biography is included in the paper, ways of upbringing recommended by Giussani, teaching/upbringing events, personality traits of an educator and a pupil are discussed and a relationship between upbringing and freedom of the individual, conscience and tradition is dealt with as well. 